forward their ideas, obtaining criticism from their fellows in all walks of life and collecting the relevant data before formulating a plan of action. Its deliberations would be almost wholly concerned with matters upon which the modern developments of science have a bearing, but it would possess no power of action nor publicity. None the less, Sir Daniel Hall suggests that in this way those responsible for government would be supplied with the services of the expert in a way comparable with that in which Fascist and Communist Governments are served.

\section{Scientific Study of Foreign Policy}

THE report on the work of the Intellectual Cooperation Organization submitted by the Sixth Committee to the Assembly of the League of Nations refers to the way in which the scientific study of problems of foreign policy is obtaining recognition as a new branch of learning. The International Studies Conference has devoted two years to the preparation of the study of peaceful change, and as a result of research in many countries a series of works on demographic problems, the distribution of raw materials and colonial questions which would offer reliable contributions to the solution of such problems is about to be published by the Institute of Intellectual Co-operation. The next two years are to be devoted to the study of economic policies in relation to world peace. An international conference on higher education held at the Institute dealt with such problems as the organization of various university faculties, scientific research and higher technical education, overcrowding in the universities and international collaboration. A Permanent Committee on Higher Education was appointed by the Conference to keep in touch with these questions. The report directs special attention to the programme of activities drawn up by the Intellectual Co-operation Organization and the Executive Committee of the International Council of Scientific Unions, which is directly connected with the advancement of all branches of science. The Organisation has also been requested to consider what steps might be taken to enable writers to continue to carry out their work with full freedom of thought and expression and a guarantee of material security. Reference is made to an international inquiry into the reorganization of secondary education, the key to the problem of overcrowding in the universities and liberal professions, and finally the report outlines a draft Act to set up and maintain National Committees on Intellectual Co-operation and to grant financial contributions to the International Institute of Intellectual Co-operation.

\section{Automatic Control for Aircraft}

ANother step towards the elimination of the physical and nervous strain upon the pilot in a long flight, caused by his having to maintain continuous manual control over the machine, has just been accomplished by the linking up of several separate devices into one synchronized piece of apparatus for use in such cases. A De Havilland "Dragon" pas- senger aircraft has been acquired by Messrs. Air Travel and Survey, of Sydney, for photographic survey work. The technique of this demands that the machine must fly on a dead straight line and a level keel for periods, and an automatic pilot that can control this while the crew attend to other photographic duties has been in existence for some time. This apparatus in its latest form, known as a 'deviator', keeps the machine on a given course, but the direction of this must be controlled by the pilot. The new apparatus adds to this a Marconi Wireless 'homing' device which sets the aircraft's course in the direction of the transmitting station, when tuned in to that wave-length. The station would normally be an aerodrome with a special call sign, but ordinary broadcasting stations may be used, provided that the pilot can identify them. He thus has nothing to do except to watch and adjust the wireless receiving apparatus as necessary. This machine was successfully demonstrated on February 17 at Croydon. It brings within sight the day when the pilot of a big aircraft will merely have to exercise a general watch over the instruments in his cabin, more comparable with the manner in which the captain of a ship controls his craft.

\section{Radio Research in India}

REFERENCE has been made from time to time in the columns of NATURE to the desirability of encouraging the carrying out in India of fundamental radio research of the type sponsored by the Radio Research Board in Great Britain. This matter was referred to in the presidential address prepared by the late Lord Rutherford for the recent Silver Jubilee meeting of the Indian Science Congress. It was pointed out that the investigations conducted in Great Britain on the propagation of radio waves over great distances have considerably increased our knowledge of the upper atmosphere. The details of the electrified regions of the atmosphere vary considerably with the hour of the day and with the season of the year as well as with geographical location. The results are of great practical importance in the selection of the most suitable wave-lengths for radio communication, and, in addition, it does not seem impossible that such studies may prove of value in long-range weather forecasting. There appears, therefore, to be scope for research on this matter in a wide field and in various parts of the world, and Lord Rutherford expressed the hope that it will be vigorously pursued in India. Reference was made to the very promising beginning that has already been effected by Profs. S. K. Mitra and M. N. Saha and their students in attacking fundamental radio problems. As an instance of the important work which is in progress in other parts of the Empire, mention was made of the admirable progress made in this field by the Australian Radio Research Board, which was established nearly ten years ago.

\section{Research in Foot-and-Mouth Disease}

THE Minister of Agriculture and Fisheries has decided to enlarge the Foot-and-Mouth Disease Research Committee. The scope of the problem 